\title{
Securing personal freedom through institutions: the role of electoral democracy and judicial independence
}

\author{
Niclas Berggren ${ }^{1,2}$ (1) $\cdot$ Jerg Gutmann ${ }^{3,4}$
}

Published online: 24 February 2020

(c) The Author(s) 2020

\begin{abstract}
We investigate empirically how electoral democracy and judicial independence relate to personal freedom. While judicial independence is positively and robustly related to personal freedom in all its forms, electoral democracy displays a robust, positive relationship with only two out of seven types of personal freedom (freedom of association, assembly and civil society; freedom of expression and information). Interaction terms and more refined indicators of the political system reveal that countries without elections or with only one political party benefit more from judicial independence than both democracies and multi-party systems without free elections.
\end{abstract}

Keywords Freedom · Democracy $\cdot$ Judicial independence $\cdot$ Political economy · Institutions

JEL Classification D63 $\cdot$ D72 $\cdot$ D78 $\cdot$ K36 $\cdot$ K38 $\cdot$ P48

Electronic supplementary material The online version of this article (https://doi.org/10.1007/s 1065 7-020-09643-9) contains supplementary material, which is available to authorized users.

Jerg Gutmann

jerg.gutmann@uni-hamburg.de

Niclas Berggren

niclas.berggren@ifn.se

1 Research Institute of Industrial Economics (IFN), Box 55665, 10215 Stockholm, Sweden

2 Department of Economics (KEKE NF), University of Economics in Prague, Prague,

Czech Republic

3 Institute of Law and Economics, University of Hamburg, Johnsallee 35, 20148 Hamburg, Germany

4 CESifo, Munich, Germany 


\section{Introduction}

For a long time, the trend towards liberal democracy was considered by many (e.g., Fukuyama 1992) to be inevitable and irreversible. ${ }^{1}$ Then, people began to notice that this might have been too optimistic. Even worse, in some countries, also in the center of Europe, liberal-democratic institutions started to crumble. These democracies did not collapse and slide back into autocracy, as we have seen so often in Latin America or Africa-electoral democracy has largely been maintained. Instead, they have started to slowly revert previous achievements, e.g., with respect to the rule of law. This raises the question how different political and legal systems safeguard personal freedom, defined as the extent to which people can make the choices they want in personal and public life without being dominated by others. Does electoral democracy suffice, or are complementary institutions, such as those guaranteeing judicial independence, needed?

Personal freedom is a widely shared desideratum. It occupies a central role in the liberal tradition-in the utilitarian approach of Mill (1859), in the contract-theory versions of Rawls (1971) and Buchanan (1977), in the Whig-inspired analysis of Hayek (1960) and in the more rights-based tradition of Locke (1689) and Nozick (1974) — but is certainly not restricted to it. Most ideologies allow for and value a personal sphere in which people can live on their own terms. Moreover, economic philosophers like Sen (1999) have stressed that human development should not be measured merely in terms of income levels and poverty rates, but freedom itself constitutes a principal goal and measure of success of development. One basic reason for putting a high value on freedom is that it seems to bring happiness to people (Verme 2009; Rahman and Veenhoven 2017); but even if it did not, it could still be deemed desirable on the basis of non-consequentialist moral theories.

We conduct the first empirical study relating personal freedom to two central political and legal institutional arrangements: democracy (defined in a minimal way as political offices being filled through contested elections) and judicial independence (defined, following Feld and Voigt 2003, as the de facto enforcement of court decisions irrespective of the interests of other government branches). ${ }^{2}$ We, thus, study the extent to which either certain political institutions and practices or certain legal institutions and practices protect personal freedom, as well as its seven constituent indicators. In addition, we offer an interaction analysis to see whether institutional complementarities exist between democracy and judicial

\footnotetext{
1 Zakaria (1997, p. 22) defines liberal democracy as "a political system marked not only by free and fair elections, but also by the rule of law, a separation of powers and the protection of basic liberties of speech, assembly, religion, and property." Mukand and Rodrik (2020) state that the distinguishing characteristic of liberal democracy is that it protects civil rights (i.e., equality before the law, also for minorities) in addition to property rights and political rights.

${ }^{2}$ We do not analyze the emergence of judicial independence or electoral democracy or consequences other than personal freedom. See instead Hayo and Voigt $(2007,2016)$ and Vanberg $(2008 \mathrm{a}, \mathrm{b})$ on what explains judicial independence, see Voigt and Gutmann (2013), Voigt et al. (2015), Gründler and Krieger (2016) and Acemoglu et al. (2019) on growth effects and see Alt and Lassen (2008) and Albanese and Sorge (2012) on corruption effects.
} 
independence - which is especially important in light of the recent rise of illiberal democracy, alluded to above. ${ }^{3}$

A priori, it is ambiguous in what direction the relationships between democracy and personal freedom and between judicial independence and personal freedom go. While democracy, in the pure electoral sense of the term, offers the majority a chance to affect policy, and while most people, including the median voter, may value personal freedom, they may nevertheless want to restrict it such that it primarily applies to themselves and their in-group. It is certainly not unheard of for majorities to curtail ways of living for various minorities or to make criticism of the government more difficult by intimidating independent media. Sometimes, majorities oppose personal freedom flat out - such as in the case of disallowing religious freedom or the freedom to form legal relationships with whomever one wants (Berggren et al. 2017; Gouda and Gutmann 2020). Still, democracy comes in different forms, and it often goes hand in hand with what one might call "widening circles of inclusion", which manifests itself in further formal and informal institutions that uphold generality in the treatment of citizens (Buchanan and Congleton 1998). This speaks in favor of democracy bringing about more personal freedom. ${ }^{4}$

When it comes to judicial independence, it is regularly seen as a means to protect personal freedom against encroachment by political decision-makers. If the judicial system is independent of the political system, if it has constitutional authority to block legislative decisions that run counter to the constitution, if there are substantive stipulations of personal freedom in the constitution or in legislative practice, and if judges value personal freedom, there is good reason to expect judicial independence to favor personal freedom. However, some of these conditions may not be fulfilled and it is therefore anything but safe that judicial independence will further the protection of personal freedom. 5

It may also be that the specific combination of democracy and judicial independence affects personal freedom. For example, in the liberal tradition, it is often asserted that majoritarian rule risks becoming oppressive if the rulers are not constrained in some manner or form, e.g., by independent legal power. Popper (2013, p. 368) stresses this:

Democracy cannot be fully characterized as the rule of the majority, although the institution of general elections is most important. For a majority might rule in a tyrannical way. (The majority of those who are less than $6 \mathrm{ft}$. high may decide that the minority of those over $6 \mathrm{ft}$. shall pay all taxes.) In a democracy, the powers of the rulers must be limited ...

\footnotetext{
${ }^{3}$ Voigt $(2013,2019)$ has recurrently emphasized the importance of considering the interplay betweenpotentially complementary or substitutive - institutions in shaping human action.

${ }^{4}$ A propos which Berlin (2002, p. 177) said: "Self-government may, on the whole, provide a better guarantee of the preservation of civil liberties than other régimes, and has been defended as such by libertarians. But there is no necessary connexion between individual liberty and democratic rule".

5 Waldron (2006, p. 1346) claims "that there is no reason to suppose that rights are better protected by this practice [judicial review] than they would be by democratic legislatures." While we acknowledge this theoretical possibility, we assert that it needs to be tested empirically, which is, in fact, what we try to do.
} 
Hence, although there are good reasons to expect an association between democracy and personal freedom, and between judicial independence and personal freedom, whether the relationship is in fact positive or negative, how strong it is and whether it is based on a combination of democracy and judicial independence, must be settled through empirical analysis. Against this background, our study uses a dataset spanning up to 162 countries to conduct a cross-sectional comparative analysis of the institutional foundations of personal freedom. We find clear indications of a positive and robust relationship between judicial independence and personal freedom, while democracy is not robustly associated with this type of freedom. When we study the interaction between democracy and judicial independence in order to test whether they are interdependent on each other in their effect on personal freedom, we find evidence that judicial independence is needed the most where there is the least electoral accountability, i.e., in political systems without elections or with only one political party.

Overall, our findings should mitigate fears that electoral democracy erodes most types of personal freedom (perhaps more common on the political right), as well as fears that judicial independence does so (perhaps more common on the political left). If anything, the opposite seems to hold, especially for judicial independence. ${ }^{6}$

\section{A simple theoretical framework}

In relating democracy and judicial independence to personal freedom, we structure our theoretical reasoning around Fig. 1. It specifies three key features of the institutional environment of any political unit: the relevant actors (politicians and judges), the outcome of the political and judicial process (legislation and executive orders, adjudication) and the level of personal freedom that results from political and judicial decisions.

Let us begin with the institutional environment, by which we mean a set of rules and practices, as a rule rooted in a constitution that specifies the structure of the state and how it is, and how it is not, to be governed. We focus on three elements: the level of democracy, the level of judicial independence ${ }^{7}$ and the de jure protection of personal freedom (as guaranteed by the constitution). All three factors matter for how the political process functions, what decisions it produces, how the legal process intervenes in or influences the political process and makes its own decisions pertaining to personal freedom, and the extent to which the resulting rules, as formed by political and judicial decisions (including their implementation), are characterized by personal freedom.

\footnotetext{
${ }^{6}$ We evaluate how personal freedom relates to different types of political/legal systems, but we are not estimating causal effects in the sense that we can be sure that an exogenously imposed change in democracy or judicial independence would result in the effect we have measured. Still, we can at the very least say something about how life under these different sets of institutions is for people.

7 Subsumed under judicial independence is judicial review (i.e., the degree to which judges are able to legally invalidate legislative acts), since without it, independence does not entail any power to act. For more about judicial review, see, e.g., Ginsburg and Versteeg (2014).
} 


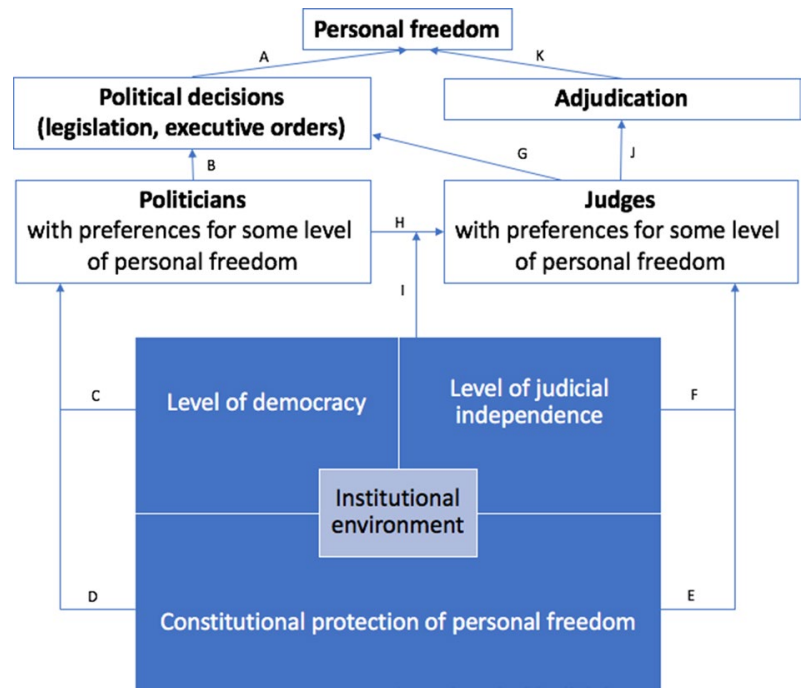

Fig. 1 The process determining the degree of personal freedom

This suggests certain links, which are indicated by the arrows and marked by letters in Fig. 1. First, consider our ultimate variable of interest, personal freedom, which is strongly shaped by political decisions (legislation and executive orders) (A). Such decisions can reduce or increase personal freedom, depending on their content. Their content is largely decided on by politicians-both of the executive and legislative kind-who act within the political system to further the satisfaction of their preferences (B). ${ }^{8}$ One distinct possibility is that they have preferences about the desirable level of personal freedom, which will influence the content of the legislative acts and executive orders they will pursue. A "libertarian" politician will put a large weight on personal freedom and will, thus, try to implement reforms to achieve more of it. An "authoritarian" politician, on the other hand, may share the libertarian's view that personal freedom is an important political factor-but she or he sees it as anathema and will try to constrain personal freedom in various ways. Less ideologically committed politicians probably pay more attention to potentially important support groups, which could be voters and organized interest groups, with their own preferences regarding personal freedom.

However, legislation takes place in a constitutional setting that not only defines the procedural rules of the political process (most important here is whether electoral democracy is in place or not; (C). In addition, the constitution also contains

\footnotetext{
${ }^{8}$ Having preferences of their own does not mean that politicians can pursue them without taking into account what the preferences of central support groups look like (Peltzman 1976). In a non-democracy, it may be easier for politicians to get their wish, but also there, they must pay attention to how to achieve support (Olson 1993).
} 
substantive rules that limit the policy space and enable the judiciary to intervene if these rules are violated.

As for substantive rules that pertain to personal freedom, e.g., about the legal process and about the character of legislation, they often contain stipulations protecting human rights. Such protections can influence both politicians (D) and judges (E)indeed, for there to be a role for judges in our setting, the constitution must contain such rules or rules which at least allow for such an interpretation. ${ }^{9}$

As for the role of the judiciary, the constitution must enable judges to safeguard the constitutionally protected personal freedom $(\mathrm{F})$ by invalidating legislation and executive orders that run counter to it $(\mathrm{G})$. Judicial independence, however, is more than judicial review: It implies the power to stop violations of the constitution without being influenced by other government branches (with $\mathrm{H}$ indicating politicians trying to steer the judiciary and with such attempts being curtailed by judicial independence, indicated by I). Without independent judges, politicians will be able to influence judicial review such that any serious critique is quenched. This could, e.g., happen if politicians only appoint loyal judges or if they exert pressure on judges to not interfere with their legislative activities. Lastly, there is the possibility that judges can affect personal freedom in other ways than by affecting political decisions in legislatures and the executive (although this is probably the most important channel), which we refer to as adjudication ( $\mathrm{J}, \mathrm{K})$. For example, in a common-law system, adjudication can affect the set of de jure institutions that define personal freedom - as if judges themselves create law. Indeed, as Ferejohn (2002, p. 41) puts it: "[C]ourts have increasingly become places where substantive policy is made". Moreover, even in other types of legal systems, judges might affect personal freedom by "reprimanding" public officials (including lower-level politicians, civil servants and lower-level judges) that do not follow the de jure rules that define personal freedom and by adjudicating against such violations.

It bears noting that any constitutional protection of personal freedom is vague, open to interpretation and non-comprehensive, which gives politicians and independent judges a certain scope of discretion when making legislation, when declaring it void or when adjudicating in other ways. The amount of discretion arguably varies between legal cultures (Cooter and Ginsburg 1996), where judicial independence is one indicator of the scope for independent decision-making by judges. But the existence of discretion explains why the preferences of political and judicial actors regarding personal freedom may play an important role for their decisions. For example, in some countries, judges may be unelected representatives of that society's (economic, political or religious) elites and could use their position to hamper social and political efforts to preserve or expand personal freedoms of the general population. Hence, if there is legislation or executive orders that reduce personal freedom, it is not clear if judges will block or invalidate them, even if the constitution contains a rule protecting this personal freedom and even if there is judicial independence. If judges do not favor personal freedom themselves, they can opt to

\footnotetext{
9 If judges are independent, politicians can be expected to be more prone to follow constitutional provisions protecting personal freedom in the first place, such that judges do not even have to intervene.
} 
remain passive or, if there is a legal case in front of them, opt to interpret (often very broad) constitutional rules such that they do not stipulate this particular personal freedom. ${ }^{10}$ Especially in common-law systems, judges may be unwilling to adjudicate in a manner that is conducive to personal freedom if they interpret the emergent body of law, broadly conceived, as not allowing for or requiring personal freedom, where this interpretation can be influenced by the personal preferences of judges. Conversely, should judges hold favorable views of personal freedom, they can often interpret rules and adjudicate cases in a way that upholds or extends it.

Against this schematic background, we now present substantive arguments about how democracy and judicial independence, the two central institutionally defined practices of Fig. 1, can, respectively, be expected to relate to personal freedom.

Regarding democracy and personal freedom whether the relationship is positive or negative depends on the preferences of the decisive actors, i.e., the politicians themselves, but also voters and interest groups.

Some scholars have predicted that unconstrained democracy would gradually erode personal freedom. ${ }^{11}$ One argument is that voters are not particularly interested in freedom (they are "afraid to be free", as Buchanan 2005, puts it), and especially populist politicians may cater to what they care about instead. Another reason might be that smaller interest groups who do not care much about personal freedom in general have an edge in influencing political decisions, in accordance with the logic of collective action (Olson 1965). Such groups typically care strongly about either preferential treatment in order to secure more material resources, e.g., through restrictions on competitors, or about their ideological goals (which could be of a general nature, of a kind that entails a dislike of personal freedom, or of a more group-oriented type, such that the group wants to secure freedom primarily for itself but not for others). Yet another reason can be the emergence of authoritarian politicians, who push an agenda to constrain freedom.

However, others predict that democracy will tend to favor personal freedom, especially when comparing it to alternative modes of governance. For example, before democracy made its appearance, it was common for certain classes of citizens to rule, with, in many cases, limited interest in the personal freedom of the population at large. Likewise, in present dictatorial systems, there is generally little regard for freedom of any kind, both exemplified by communist and Islamist rulers who force their own view of the good life vehemently on others (Gouda and Gutmann 2020). Yet another factor to consider is the general development of a postmaterialist orientation, which may entail both "liberty aspirations" and democratization (Welzel and Inglehart 2005). Liberty aspirations are a key driver of democratization, because democracy generally implies civil and political freedom. It may be that personal freedom follows from the same logic. This points at the possibility of a deep

\footnotetext{
10 One example is the decision of the U.S. Supreme Court in 2015 in Obergefell $v$. Hodges to the effect that the Fourteenth Amendment requires all states to allow for same-sex marriage and recognize samesex marriages allowed for in other states. While five justices voted in favor, four dissented, which seems to confirm that there is scope for interpretation, possibly influenced by personal preferences.

11 See, e.g., Hayek (1960), Buchanan and Congleton (1998) and Nientiedt and Köhler (2016).
} 
connection between democracy and personal freedom: the former is the result of a desire to "rule oneself", which in turn can be seen as being closely associated with a similar desire in private life. ${ }^{12}$ Indeed, Kelsen (1955) sees democracy (the "principle of majority") as being based on the idea that the social order is in concordance with as many subjects as possible and in discordance with as few as possible. He, thus, thinks that the principle of simple majority secures the highest degree of political freedom possible. If such a way of thinking underlies collective decision-making, it follows relatively straightforwardly that there is a desire of people to rule themselves on an individual level as well.

Regarding judicial independence and personal freedom there are also arguments both for a positive and for a negative relationship. One argument depends on a sociological or ideological characterization of judges. If judges are part of a conservative bourgeoisie, they may be willing, to the extent that discretion allows them, to keep personal freedom restricted in certain areas (e.g., with regard to rights for women or gay people) and to enhance it in others (e.g., with regard to the rule of law or freedom of speech). If they are more classically liberal, or more progressive, they might be inclined to decide in different ways with regard to personal freedom. In other words, personal convictions can motivate judicial decision-making, not least enabled by judicial independence. ${ }^{13}$ To this one can add that independent judges can make the influence of interest groups in the political process stronger, as suggested by Landes and Posner (1975). This effect arises because judicial independence makes agreements between interest groups and legislators more durable by the willingness of independent judges to uphold the decisions of previous legislatures, in line with the intent of original legislators. Depending on the agenda of the interest groups that successfully strike deals with politicians, personal freedom can be enhanced or deteriorate as a result.

Regarding combinations of democracy and judicial independence one can imagine four types: democracy without judicial independence ("pure electoral/populist/ illiberal democracy"), democracy with judicial independence ("liberal/constitutional democracy"), non-democracy without judicial independence ("pure dictatorship") and non-democracy with judicial independence ("power-sharing authoritarianism"). If one focuses on the two democratic alternatives, a key question is if liberal democracy is better able to secure personal freedom than illiberal democracy-which depends on the relative degree to which political and judicial decision-makers in each case care about, or think that their power depends on championing, such freedom. On the one hand, an independent judiciary can, under certain conditions, make legislative outcomes more compatible with personal freedom, if it aids in blocking

\footnotetext{
12 Even though Vanberg (2008a, b, p. 139) thinks that democracy has a tendency to erode personal freedom, he argues for a conceptual affinity: Democracy and liberalism, he claims, "share as their common normative foundation the principle of individual sovereignty, and their respective core ideals, the liberal principle of private autonomy and the democratic principle of citizen sovereignty, can be best understood as applications of the ideal of individual sovereignty to the realm of the private law society on the one side and to the "public' realm of collective-political choice on the other".

13 On how American judges are-and are not—influenced by political convictions, see Sunstein et al. (2006).
} 
illiberal politicians or politicians with constituencies that do not favor freedom; on the other hand, judges themselves may not favor freedom and could instead use their discretionary power to the benefit of established interests. ${ }^{14}$

\section{Data and empirical strategy}

Our main dependent variable is personal freedom. It denotes the extent to which people can make the choices they want without being dominated by others, and it is measured by a composite index that forms one half of the Human Freedom Index (Vásquez and Porčnik 2018). ${ }^{15}$ The personal freedom index, in turn, also consists of two parts: legal protection and security as well as a set of specific personal freedoms. ${ }^{16}$ The first part consists of two indicators: one for the rule of law and one for security and safety. The second part consists of five indicators measuring freedom of movement; religion; association, assembly and civil society; expression and information; identity and relationships. Each indicator is made up of more detailed variables, which are specified in Table A1 in the online supplementary material. The indicators are measured on a $0-10$ scale, with 10 representing the highest level of personal freedom, and each indicator is calculated as the mean value of the variables on the level of aggregation underneath. This implies that the two main parts of personal freedom are given the same weight. The index covers up to 162 countries and reflects the situation in 2016. A limitation of the Human Freedom Index is that it has been produced only for a couple of years and with a changing methodology and country coverage. Thus, conducting a panel data analysis would not be possible.

Our explanatory variables of interest are two central institutional indicators. Our preferred measure of democracy was conceptualized and measured by Cheibub et al. (2010). Their dataset has been updated and extended by Bjørnskov and Rode (2020). The measure is dichotomous, with a 0 given to a country if political offices are not filled through contested elections and a 1 otherwise. ${ }^{17}$ The main reason why this narrowly defined indicator is optimal for our research design is that we are interested in separating the effect of electoral competition for public offices from that of constraints on executive power exercised by an independent judiciary, which is our second indicator. To give a more nuanced picture in our interaction analysis, we rely

\footnotetext{
${ }^{14} \mathrm{We}$ are not the first ones to explicitly analyze the institutional complementarity between democracy and judicial independence. Chen and Yang (2017), for example, show that both democracy and judicial independence are associated with better corporate governance and that these effects are mutually reinforcing.

15 The other half measures economic freedom and is outside the scope of our study.

16 The idea behind the first part is the following: "Without the rule of law and security, specific freedoms cannot, in a practical sense, be lived out. The rule of law and security are essential to provide reasonable assurance that life is protected. Security and safety are fundamental for survival and for the exercise of a vast array of freedoms" (Vásquez and Porčnik 2018, p. 16).

${ }^{17}$ Cheibub et al. (2010) offer methodological arguments for why their indicator is superior in many applications to alternative ones, such as that of the Polity project, that include many other aspects of the political system. For a conceptual-philosophical defense of a dichotomous definition, see Popper (2013, p. 268).
} 
on the indicator electoral, which is also provided by Bjørnskov and Rode (2020) and further distinguishes among non-democratic political regimes. Electoral allows us to differentiate between multi-party non-democracies on the one hand and nondemocracies with only one party or without elections on the other hand. Our preferred measure of de facto judicial independence was introduced by Linzer and Staton (2015). Their indicator measures not only whether judges are autonomous but also whether they are influential in the sense that their decisions are implemented by the other branches of government and thus greatly constrain the choices of political actors. They develop a latent variable measurement model to produce their dataset, which has been updated in Staton et al. (2019). In robustness checks, we replace our indicators of democracy and judicial independence with indicators introduced by Geddes et al. (2014) and the V-DEM project (Pemstein et al. 2018).

In addition, we use the following control variables: log-income per capita (higherincome countries should have more personal freedom, as demand for freedom increases when material circumstances are satisfactory; Welzel et al. 2003); log-population size (reflecting increasing collective action problems among those demanding freedoms; Olson 1965); whether the country has been a British, a French, a Spanish or no colony (colonial heritage may affect personal freedom today; Lange 2004); abundance of natural resources (the share of natural resource rents in GDP, since personal freedom may suffer from rent-seeking related to the control of these resources; Al-Ubaydli 2012); and religiosity (the share of the population stating that religion is an important part of daily life is expected to favor less personal freedom due to the common conviction among religious people that an objective and restrictive morality exists; Berggren 2016, or Berggren and Bjørnskov 2013). As an alternative to colonial history, we also show results controlling for British and French legal origins, as categorized by La Porta et al. (2008). La Porta et al. cite Hayek (1960) who argues that the differences in these legal systems reflect profound differences in philosophies of freedom.

In our study, all explanatory variables are measured in 2010. This time lag reduces concerns about simultaneity between personal freedom and our indicators of democracy and judicial independence. Moreover, continuous indicators are standardized to have a mean value of zero and a standard deviation of one to facilitate their interpretation.

Descriptive statistics are presented in Table 1. Personal freedom is quite high in most countries, with mean values of 7 and more for the constituent parts, except for the rule of law. Based on the classification of Bjørnskov and Rode (2020), 59\% of the countries in our sample are democratic and another $30 \%$ are multi-party nondemocratic systems. Almost $40 \%$ of the countries have never been colonized and, among the others, the most frequent colonizer is the British Empire (28\% of all countries). Nevertheless, French legal origin countries are much more common in our sample (56\%) than common law countries $(29 \%)$. The countries included, with their values for personal freedom, democracy and judicial independence, are presented in Table A2 in the online supplementary material.

Our empirical strategy can be described as follows. We regress the personal freedom index, as well as the main components it consists of, on our two explanatory variables of interest, democracy and judicial independence. We control, in all model 
Table 1 Descriptive statistics

\begin{tabular}{lcrccc}
\hline & N & Mean & SD & Min & Max \\
\hline Personal Freedom Index & 162 & 6.98 & 1.49 & 2.17 & 9.40 \\
Rule of Law & 162 & 5.11 & 1.63 & 1.98 & 8.69 \\
Security and Safety & 162 & 8.07 & 1.42 & 3.96 & 9.96 \\
Freedom of Movement & 162 & 7.66 & 2.76 & 0.00 & 10.00 \\
Freedom of Religion & 161 & 7.48 & 1.64 & 0.00 & 9.85 \\
Freedom of Association and Assembly & 136 & 7.11 & 2.77 & 0.50 & 10.00 \\
Freedom of Expression and Information & 162 & 7.69 & 1.62 & 1.76 & 9.80 \\
Freedom of Identity and Relationships & 162 & 6.98 & 3.09 & 0.00 & 10.00 \\
Judicial Independence (Staton et al.) & 162 & -0.00 & 1.00 & -1.75 & 1.68 \\
Judicial Independence (V-DEM) & 158 & 0.00 & 1.00 & -2.27 & 2.16 \\
Multi-party System (Bjørnskov and Rode) & 162 & 0.30 & 0.46 & 0 & 1 \\
Democracy (Bjørnskov and Rode) & 162 & 0.59 & 0.49 & 0 & 1 \\
Democracy (Geddes et al.) & 162 & 0.67 & 0.47 & 0 & 1 \\
Log-Income & 162 & -0.00 & 1.00 & -2.03 & 1.99 \\
Log-Population & 162 & -0.00 & 1.00 & -2.81 & 2.96 \\
British Colony & 162 & 0.28 & 0.45 & 0 & 1 \\
French Colony & 162 & 0.15 & 0.36 & 0 & 1 \\
No Colony & 162 & 0.39 & 0.49 & 0 & 1 \\
Spanish Colony & 162 & 0.10 & 0.31 & 0 & 1 \\
Natural Resources & 161 & -0.00 & 1.00 & -0.75 & 3.79 \\
Religiosity & 139 & -0.00 & 1.00 & -2.30 & 1.05 \\
Common Law & 162 & 0.29 & 0.46 & 0 & 1 \\
French Civil Law & 162 & 0.56 & 0.50 & 0 & 1 \\
\hline & & & & &
\end{tabular}

specifications, for the logarithm of income per capita and population size. Then we add control variables for a country's colonial history, as well as for the importance of natural resources and religion in a society. As an alternative to colonial history, we control for legal origins. All reported standard errors are robust to heteroscedasticity. An obvious limitation of our empirical design is that our empirical evidence is based on conditional correlations, rather than causal estimates with a strong identification strategy. What we show is under what conditions personal freedom is systematically more likely to prosper, but we cannot claim to offer strong evidence that a specific institution causes the protection of personal freedom. ${ }^{18}$

\footnotetext{
${ }^{18}$ In all regression models based on our full sample of 162 countries, we include a dummy variable for Brunei, which constitutes an outlier in our analysis (see the online supplementary material for more).
} 


\section{The results}

\subsection{Bivariate plots}

To get a basic feeling for the bivariate relationships between personal freedom and our institutional variables of interest, we illustrate them graphically in Fig. 2. The left-hand plot shows a clear positive relationship between judicial independence and personal freedom (with Brunei as an outlier). The right-hand plot shows the personal freedom of three systems of government: democracy, multi-party systems without free elections and systems without elections or with only one party. Democracies have the highest degree of personal freedom, multi-party systems have the second-highest degree of personal freedom (with Iraq and Syria scoring exceptionally low) and systems without elections or with only one party have the lowest level of personal freedom (with Yemen scoring the lowest). However, the confidence intervals are rather wide, so it is not clear that these differences are statistically significant. Moreover, these results could hide a number of confounding factors, which is why we now turn to regression analysis.
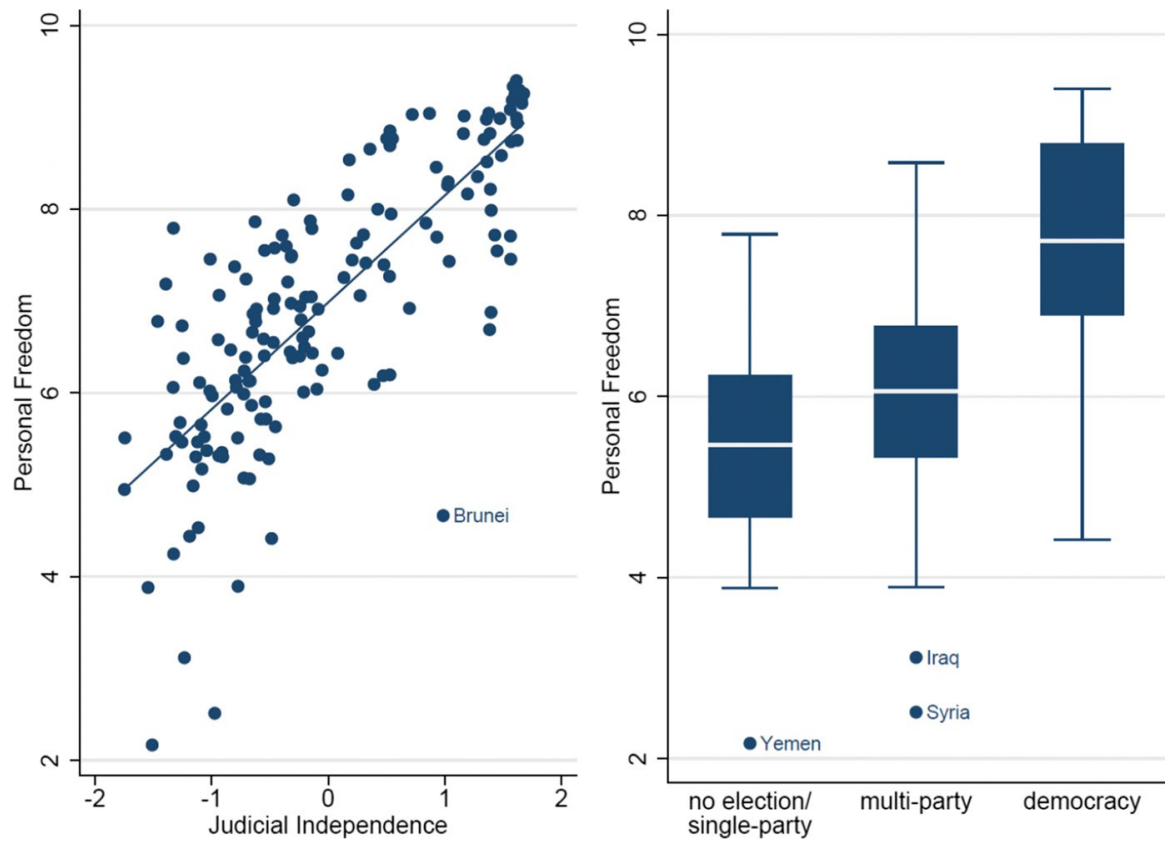

Fig. 2 The relation of personal freedom to judicial independence and the political systems 
Table 2 Predictors of personal freedom

\begin{tabular}{|c|c|c|c|c|c|}
\hline & (1) & (2) & (3) & (4) & (5) \\
\hline Judicial independence & $\begin{array}{l}0.876 * * * \\
(0.107)\end{array}$ & $\begin{array}{l}0.888 * * * \\
(0.105)\end{array}$ & $\begin{array}{l}0.735 * * * \\
(0.092)\end{array}$ & $\begin{array}{l}0.869 * * * \\
(0.109)\end{array}$ & $\begin{array}{l}0.735 * * * \\
(0.095)\end{array}$ \\
\hline Democracy & $\begin{array}{l}0.535^{* * * *} \\
(0.159)\end{array}$ & $\begin{array}{l}0.385^{*} \\
(0.168)\end{array}$ & $\begin{array}{l}0.308 \\
(0.180)\end{array}$ & $\begin{array}{l}0.480 * * \\
(0.157)\end{array}$ & $\begin{array}{l}0.341 * \\
(0.165)\end{array}$ \\
\hline Log-income & $\begin{array}{l}0.173 \\
(0.094)\end{array}$ & $\begin{array}{l}0.124 \\
(0.093)\end{array}$ & $\begin{array}{l}0.123 \\
(0.092)\end{array}$ & $\begin{array}{l}0.104 \\
(0.094)\end{array}$ & $\begin{array}{l}0.046 \\
(0.090)\end{array}$ \\
\hline Log-population & $\begin{array}{l}-0.146^{*} \\
(0.065)\end{array}$ & $\begin{array}{l}-0.194 * * \\
(0.062)\end{array}$ & $\begin{array}{l}-0.218 * * * \\
(0.061)\end{array}$ & $\begin{array}{l}-0.156^{*} \\
(0.064)\end{array}$ & $\begin{array}{l}-0.205^{* *} \\
(0.065)\end{array}$ \\
\hline Brunei & $\begin{array}{l}-3.391 * * * \\
(0.197)\end{array}$ & $\begin{array}{l}-3.027^{* * * *} \\
(0.218)\end{array}$ & & $\begin{array}{l}-3.083^{* * * *} \\
(0.225)\end{array}$ & \\
\hline British colony & & $\begin{array}{l}-0.358 \\
(0.279)\end{array}$ & $\begin{array}{l}-0.655^{*} \\
(0.324)\end{array}$ & & \\
\hline French colony & & $\begin{array}{l}0.330 \\
(0.333)\end{array}$ & $\begin{array}{l}0.114 \\
(0.368)\end{array}$ & & \\
\hline No colony & & $\begin{array}{l}0.391 \\
(0.261)\end{array}$ & $\begin{array}{l}-0.190 \\
(0.309)\end{array}$ & & \\
\hline Spanish colony & & $\begin{array}{l}0.302 \\
(0.271)\end{array}$ & $\begin{array}{l}-0.104 \\
(0.314)\end{array}$ & & \\
\hline Natural resources & & & $\begin{array}{l}-0.322 * * \\
(0.105)\end{array}$ & & $\begin{array}{l}-0.302 * \\
(0.117)\end{array}$ \\
\hline Religiosity & & & $\begin{array}{l}-0.262^{* * * *} \\
(0.077)\end{array}$ & & $\begin{array}{l}-0.272 * * * \\
(0.069)\end{array}$ \\
\hline Common law & & & & $\begin{array}{l}-0.844 * * * \\
(0.164)\end{array}$ & $\begin{array}{l}-0.503 * * \\
(0.172)\end{array}$ \\
\hline French civil law & & & & $\begin{array}{l}-0.597^{* * * *} \\
(0.147)\end{array}$ & $\begin{array}{l}-0.257 \\
(0.137)\end{array}$ \\
\hline Constant & $\begin{array}{l}6.689 * * * \\
(0.128)\end{array}$ & $\begin{array}{l}6.642 * * * \\
(0.258)\end{array}$ & $\begin{array}{l}7.083 * * * \\
(0.291)\end{array}$ & $\begin{array}{l}7.300 * * * \\
(0.168)\end{array}$ & $\begin{array}{l}7.121 * * * \\
(0.181)\end{array}$ \\
\hline$N$ & 162 & 162 & 138 & 162 & 138 \\
\hline$R^{2}$ & 0.675 & 0.716 & 0.786 & 0.703 & 0.768 \\
\hline
\end{tabular}

OLS regression coefficients, robust standard errors in parentheses, ${ }^{*} p<0.05 ; * * p<0.01 ; * * * p<0.001$

\subsection{Findings for the personal freedom index}

Our main findings are reported in Table 2, in which we gradually add more control variables to our baseline specification. Both judicial independence and democracy are positively related to personal freedom, but democracy is not as robust a predictor, as it loses statistical significance when control variables are added. Hence, we regard judicial independence as the more robust institutional safeguard of personal freedom. An increase in judicial independence of one standard deviation is associated with an increase in personal freedom of roughly 0.8 points, which corresponds to the difference between Colombia (located at the 


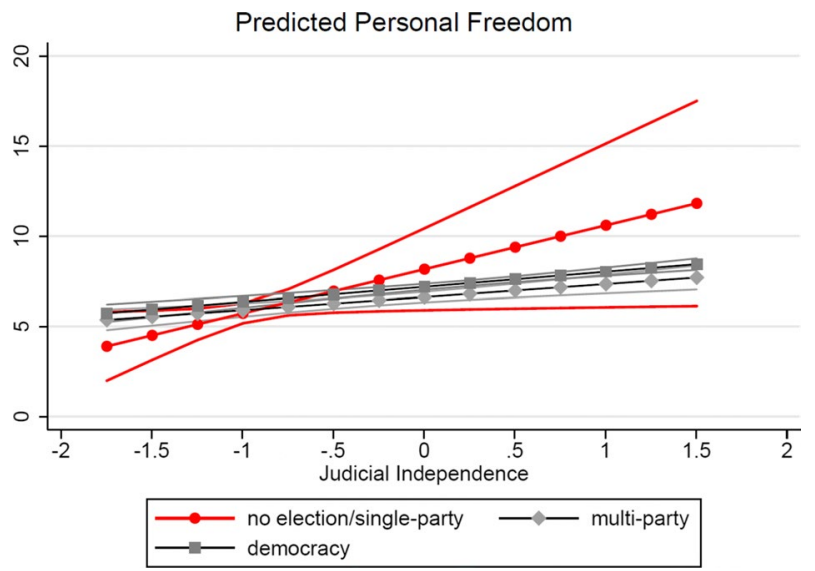

Fig. 3 Interaction effects with regard to personal freedom, results based on Table A10. Predicted values with $95 \%$ confidence intervals

mean value of the sample, 7.0) and Serbia (7.8). As for control variables, we find evidence that larger countries, countries more dependent on natural resources and those with a more religious population show lower levels of personal freedom. Interestingly, countries with a legal system based on common law are associated with reduced personal freedom, which is in stark contrast to the arguments proposed by La Porta et al. (2008). ${ }^{19}$ Our results also show how strong an outlier Brunei is (the dummy is not included in columns 3 and 5, because the country is not in the sample).

Our findings align well with those of Abouharb et al. (2013), who relate judicial independence to physical integrity rights and find a positive association, indicating the relevance of the design of legal institutions for policies that concern a protected individual sphere. Similarly, Crabtree and Nelson (2017) find a robust relationship between judicial independence and improvements in empowerment rights. Since both physical integrity rights and empowerment rights are more narrow concepts than our dependent variable, personal freedom, our findings support and generalize the results of those previous studies.

To test for potential complementarities between democracy and judicial independence in their effect on personal freedom, we estimate conditional effects using interaction terms. To give a more nuanced picture, we interact judicial independence not only with democracy but also with other types of political system: multi-party systems without free elections, single-party systems and systems with no elections at all. The two latter categories are merged into one due to few observations. Regression tables are not suitable for interpreting the results of such interaction models (Brambor et al. 2006; Berry et al. 2012). Thus, we interpret the predictive margins

\footnotetext{
${ }^{19}$ One illustration of why this result obtains is that former British colonies largely retain laws prohibiting homosexual conduct (Han and O'Mahoney 2014).
} 
presented in Fig. 3. Regression results including the interaction terms are available in Table A10 in the online supplementary material.

Figure 3 shows the predicted level of personal freedom based on our model estimates and conditional on the level of judicial independence as well as the type of political system. One obvious conclusion can be drawn: Countries without elections or with only a single party benefit more than other countries from having an independent judiciary. ${ }^{20}$ However, the effect of judicial independence is imprecisely estimated in these least democratic political systems and is thus not statistically distinguishable from the effect in more democratic countries. This suggests that judicial independence contributes in all political systems to higher personal freedom and while the effect appears to be largest in the least democratic countries, it is also more difficult to predict the consequences of judicial independence in these countries.

\subsection{Findings for the seven areas of personal freedom}

Now we continue with a more fine-grained analysis, by applying the same model as before, but with one of the seven areas of the personal freedom index at a time as the dependent variable. The results for our explanatory variables of interest, based on regressions with the same model as in Table 2, column 1, are summarized in Table 3; the full regression results are shown in Tables A3-A9 in the online supplementary material.

First, we use our model to predict the rule of law. Table 3 indicates that judicial independence is positively and robustly related to it: The more independent judges are, the better are the working properties and the stronger are the generality characteristics of the legal system. ${ }^{21}$ In contrast, electoral democracy does not seem related to the rule of law at all. The latter observation underlines the relevance of Mukand and Rodrik's (2020) distinction between liberal and illiberal democracy, where only the former protects the rights of minorities.

Table A3 in the online supplementary material further illustrates that the rule of law is strongly positively associated with income per capita (cf. Gutmann and Voigt 2018). None of the other areas of personal freedom are positively correlated with income per capita, nor is the overall personal freedom index. This is an important observation, because it shows that aside from the rule of law, most aspects of personal freedom are not a privilege of rich countries. Finally, consistent with the results of Berggren and Bjørnskov (2013), we find that religiosity is detrimental to the rule of law.

\footnotetext{
${ }^{20}$ It might appear from Fig. 3 that with the help of judicial independence highly non-democratic countries can reach much higher levels of personal freedom than democratic countries. However, these are out-of-sample predictions, as no country in this group, aside from Brunei, reaches positive judicial independence levels (see Figure A1 in the online supplementary material).

21 That judicial independence displays a robust positive relationship with the rule of law is not surprising given that the former is a necessary condition for implementing the latter (Gutmann and Voigt 2018). However, the two concepts are distinct, which merits relating them empirically.
} 


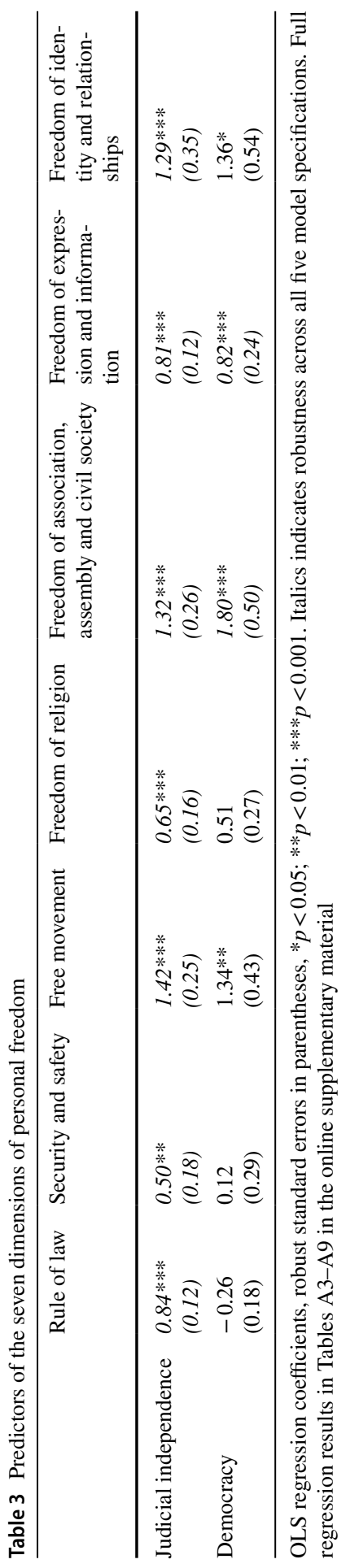


Second, we look at predictors of security and safety. Table 3 reveals a positive and robust association between judicial independence and security and safety, but none between electoral democracy and security and safety. Both common law and French civil law countries show reduced levels of security and safety.

Third, we look at predictors of free movement. While the freedom of movement benefits from judicial independence, its positive relationship with democracy is not robust to adding further control variables. Restrictions on free movement become more likely as the population size of a country increases and as natural resources become more important.

Fourth, we look at predictors of freedom of religion. We observe a statistically significant positive correlation between judicial independence and freedom of religion in Table 3, but no correlation between democracy and freedom of religion. Wealthier and larger countries enjoy less freedom of religion.

Fifth, judicial independence is positively related to freedom of association, assembly and civil society. We have argued above that democracy tends to come with more freedom of association and assembly, and indeed our regression results confirm that. This is the first dimension of personal freedom with which democracy exhibits a robust relationship. Our covariates indicate once more that if La Porta et al. (2008) are correct about the positive traits of common law for economic freedom, these effects do not generalize to personal freedom. Former French colonies show significantly increased levels of freedom, whereas common law countries are linked to reduced levels of freedom of association, assembly and civil society.

Sixth, we look at predictors of freedom of expression and information. Both judicial independence and democracy show positive effects; and as for other explanatory variables, common law countries exhibit reduced levels of the freedom of expression and information.

Finally, we come to predictors of the freedom of identity and relationships. Only judicial independence, but not democracy, is robustly related to this type of freedom. We find that freedom of identity and relationships is substantially lower in former British colonies and in societies for which natural resources and religion play an important role.

Next, we conduct the same interaction analysis as in Sect. 4.2, but for each dimension of personal freedom individually. Predictive margins, analogous to Fig. 3, are displayed in Figures A2-A8 and regression results in Tables A11-A17 in the online supplementary material.

For the rule of law, we find the same pattern as for personal freedom in general: Countries with no elections or only a single party benefit more from judicial independence in terms of gaining rule of law than other political systems. This is the only regression model in which the interaction terms between our indicators of political and legal institutions are jointly statistically significant. Although the other statistical tests for conditional effects are not significant, the estimated relationships look very similar: For five out of seven dimensions of personal freedom, the effect of judicial independence is more pronounced (and less precisely estimated) in countries without political elections or with only a single party, when compared to other countries. Only the freedoms of association, assembly and civil society as well as religion do not exhibit this pattern. Although we face problems in precisely 
estimating the effect of judicial independence in the least democratic countries, the evidence suggests that independent judiciaries in such countries would have a larger positive effect on personal freedom than elsewhere.

\subsection{Robustness checks}

We run the following tests on all model specifications and dependent variables we have tested up to this point: (1) We replace the indicator of judicial independence with the mean value of high and low court independence as measured by the V-DEM project (Pemstein et al. 2018); (2) we replace the binary indicator of democracy with one constructed by Geddes et al. (2014); (3) we exclude countries with an income above 15,000 USD from the sample; (4) we add indicators for the shares of Catholics, Muslims, Protestants and nonreligious people as control variables to every model specification; (5-7) we alternatingly exclude countries with a Catholic, Muslim or Protestant majority population; (8-13) we alternatingly exclude countries from one of six world regions. In the following, we summarize the results of these robustness checks. Regression tables are available upon request.

Regarding the robustness of our main dependent variable, the results of 65 regression models (five model specifications per robustness check) are easily summarized. The correlation between personal freedom and judicial independence is always statistically significant at the $0.1 \%$ level. In contrast, democracy is oftentimes not significantly correlated with personal freedom at the $5 \%$ level. One pattern is striking: When the share of Muslims in the population is controlled for (which itself is linked to significantly less personal freedom), when Muslim-majority countries are dropped from the sample or when countries in the MENA region are excluded, the democracy indicator seizes to show a statistically significant effect (in 14 of the 15 estimated models). This is consistent with empirical results showing that Muslim countries are less likely to implement the rule of law (Gutmann and Voigt 2015) and more likely to discriminate against religious minorities (Gouda and Gutmann 2020), and that even second-generation immigrants who stem from Muslim countries are less tolerant than other second-generation immigrants (Berggren et al. 2019).

One concern with our cross-sectional research design is that the time at which variables are measured may matter for our results. We thus re-estimate Table 2, but instead of using data for democracy and judicial independence from 2010, we use data from 2000, 2005 or 2015. The results are shown in Tables A18-A20 in the online supplementary material. Our results turn out to be robust also to this modification. Only the relationship between democracy and personal freedom is less likely to reach statistical significance.

The results of our robustness checks remain very similar when we estimate 455 regression models for the seven dimensions of personal freedom. Judicial independence remains statistically significant in most of these model specifications, whereas the size and the sign of the coefficient for democracy varies and it is very often not statistically significant. One notable exception are the 65 regression models in which security and safety is the dependent variable. In almost $50 \%$ of these models, the coefficient on judicial independence is not statistically significant. 
Neumayer and Plümper (2017, p. 36) define robustness as "the degree to which the baseline model's estimated effect of interest is supported by another robustness test model that makes a plausible change in model specification." We have conducted various such plausible changes by varying the measurement of our dependent and independent variables, the set of control variables and the regression sample (jackknife tests). Overall, the evidence for a positive relationship between judicial independence and personal freedom is highly robust, whereas the positive relationship between democracy and personal freedom is not.

\section{Concluding remarks}

Personal freedom enables people to make the choices they want, within the framework of a system of general rules and their enforcement. Arguably, many people value such freedom highly, since it is the freedom to carry out "experiments in living" and to live life as one pleases, which brings life satisfaction. Against this background, it becomes paramount to find out what can safeguard such freedom.

In this study, we propose that two institutionally grounded practices-electoral democracy and judicial independence — can be expected to influence personal freedom. However, there are theoretical arguments for both a positive and negative relationship, which calls for an empirical investigation.

Our regression analysis reveals that judicial independence is a robust predictor of personal freedom in all its forms. The more power independent judges have to make legal decisions that "bite", the higher is the degree to which people are free to make their own decisions in life. Democracy is only robustly associated with the freedom of association, assembly and civil society and the freedom of expression and information. These are classically associated with democratic decision-making, but the democratic process does not seem to produce personal freedom beyond those rights required for its own functioning.

Although judicial independence always contributes to more extensive personal freedom, our evidence suggests that it more effectively does so where the electoral accountability of politicians is completely absent. Note that this is a marginal effect indicating that more judicial independence is related to more personal freedom in these countries than in democracies, which is not to say that their levels of personal freedom are higher-quite the opposite.

Moreover, proponents of the superiority of the common law legal tradition (such as La Porta et al. 2008) might have paid too much attention to economic freedom, as our results indicate that the common law is not at all good for personal freedom. Neither is a strong presence of natural resources or religiosity-quite the opposite. Finally, our observation that the rule of law is the only area of personal freedom that is (positively) associated with income per capita shows that personal freedom can not only be enjoyed in rich societies.

Admittedly, our analysis has its limitations: It is cross-sectional and correlational in nature. Still, we suggest that it brings an important issue to the table and makes some progress in understanding what might secure personal freedom. 
Acknowledgements Open Access funding provided by Projekt DEAL. The authors wish to thank two anonymous referees, Daniel Bennett, Christian Bjørnskov, Jeremy Kidd, Hugo Montesinos-Yufa, as well as participants at the 2018 conference of the Southern Economic Association in Washington, D.C., the 2019 Danish Public Choice Workshop in Aarhus, the 2019 Public Choice Society conference in Louisville, the 2019 European Association of Law and Economics conference in Tel Aviv and the Colloquium on the Foundations of the Market Order at Leipzig University, for valuable advice. Financial support from Jan Wallanders and Tom Hedelius stiftelse and Tore Browaldhs stiftelse (Grant P19-0180), Johan och Jakob Söderbergs Stiftelse (Grant 47/19), the Czech Science Foundation (GA ČR) (Grant 19-03102S) and the German Research Foundation (Grant 381589259) is gratefully acknowledged.

\section{Compliance with ethical standards}

Conflict of interest The authors declare that they have no conflict of interest.

Open Access This article is licensed under a Creative Commons Attribution 4.0 International License, which permits use, sharing, adaptation, distribution and reproduction in any medium or format, as long as you give appropriate credit to the original author(s) and the source, provide a link to the Creative Commons licence, and indicate if changes were made. The images or other third party material in this article are included in the article's Creative Commons licence, unless indicated otherwise in a credit line to the material. If material is not included in the article's Creative Commons licence and your intended use is not permitted by statutory regulation or exceeds the permitted use, you will need to obtain permission directly from the copyright holder. To view a copy of this licence, visit http://creativecommons.org/licen ses/by/4.0/.

\section{References}

Abouharb, M. R., Moyer, L. P., \& Schmidt, M. (2013). De facto judicial independence and physical integrity rights. Journal of Human Rights, 12(4), 367-396.

Acemoglu, D., Naidu, S., Restrepo, P., \& Robinson, J. A. (2019). Democracy does cause growth. Journal of Political Economy, 127(1), 47-100.

Albanese, G., \& Sorge, M. M. (2012). The role of the judiciary in the public decision-making process. Economics and Politics, 24(1), 1-23.

Alt, J. E., \& Lassen, D. D. (2008). Political and judicial checks on corruption: Evidence from American state governments. Economics and Politics, 20(1), 33-61.

Al-Ubaydli, O. (2012). Natural resources and the tradeoff between authoritarianism and development. Journal of Economic Behavior and Organization, 81(1), 137-152.

Berggren, N. (2016). Does belief in objective morality lead to coercion? An analysis of the arguments of Kelsen and Buchanan. Review of Austrian Economics, 29(3), 315-326.

Berggren, N., \& Bjørnskov, C. (2013). Does religiosity promote property rights and the rule of law? Journal of Institutional Economics, 9(2), 161-185.

Berggren, N., Bjørnskov, C., \& Nilsson, T. (2017). What aspects of society matter for the quality of life of a minority? Global evidence from the new Gay Happiness Index. Social Indicators Research, 132(3), 1163-1192.

Berggren, N., Ljunge, M., \& Nilsson, T. (2019). Roots of tolerance among second-generation immigrants. Journal of Institutional Economics, 15(6), 999-1016.

Berlin, I. (2002). Liberty: Incorporating four essays on liberty. Oxford: Oxford University Press.

Berry, W. D., Golder, M., \& Milton, D. (2012). Improving tests of theories positing interaction. Journal of Politics, 74(3), 653-671.

Bjørnskov, C., \& Rode, M. (2020). Regime types and regime change: A new dataset. Review of International Organizations (forthcoming). www.christianbjoernskov.com.

Brambor, T., Clark, W. R., \& Golder, M. (2006). Understanding interaction models: Improving empirical analyses. Political Analysis, 14(1), 63-82. 
Buchanan, J. M. (1977). Freedom in constitutional contract: Perspectives of a political economist. College Station: Texas A\&M University Press.

Buchanan, J. M. (2005). Afraid to be free: Dependency as desideratum. Public Choice, 124(1-2), 19-31.

Buchanan, J. M., \& Congleton, R. D. (1998). Politics by principle, not interest: Toward nondiscriminatory democracy. Cambridge: Cambridge University Press.

Cheibub, J. A., Gandhi, J., \& Vreeland, J. R. (2010). Democracy and dictatorship revisited. Public Choice, 143(1-2), 67-101.

Chen, N., \& Yang, T.-C. (2017). Democracy, rule of law and corporate governance: A liquidity perspective. Economics of Governance, 18(1), 35-70.

Cooter, R. D., \& Ginsburg, T. (1996). Comparative judicial discretion: An empirical test of economic models. International Review of Law and Economics, 16(3), 295-313.

Crabtree, C., \& Nelson, M. J. (2017). New evidence for a positive relationship between de facto judicial independence and state respect for empowerment rights. International Studies Quarterly, 61(1), 210-224.

Feld, L. P., \& Voigt, S. (2003). Economic growth and judicial independence: Cross-country evidence using a new set of indicators. European Journal of Political Economy, 19(3), 497-527.

Ferejohn, J. (2002). Judicializing politics, politicizing law. Law and Contemporary Problems, 65(3), 41-68.

Fukuyama, F. (1992). The end of history and the last man. New York: Free Press.

Geddes, B., Wright, J., \& Frantz, E. (2014). Autocratic breakdown and regime transitions: A new data set. Perspectives on Politics, 12(2), 313-331.

Ginsburg, T., \& Versteeg, M. (2014). Why do countries adopt constitutional review? Journal of Law Economics and Organization, 30(3), 587-622.

Gouda, M., \& Gutmann, J. (2020). Islamic constitutions and religious minorities. Public Choice (forthcoming).

Gründler, K., \& Krieger, T. (2016). Democracy and growth: Evidence from a machine learning indicator. European Journal of Political Economy, 45(Supplement December), 85-107.

Gutmann, J., \& Voigt, S. (2015). The rule of law and constitutionalism in Muslim countries. Public Choice, 162(3-4), 351-380.

Gutmann, J., \& Voigt, S. (2018). The rule of law: Measurement and deep roots. European Journal of Political Economy, 54(September), 68-82.

Han, E., \& O'Mahoney, J. (2014). British colonialism and the criminalization of homosexuality. Cambridge Review of International Affairs, 27(2), 268-288.

Hayek, F. A. (1960). The constitution of liberty. Chicago: University of Chicago Press.

Hayo, B., \& Voigt, S. (2007). Explaining de facto judicial independence. International Review of Law and Economics, 27(3), 269-290.

Hayo, B., \& Voigt, S. (2016). Explaining constitutional change: The case of judicial independence. International Review of Law and Economics, 48(October), 1-13.

Kelsen, H. (1955). Foundations of democracy. Ethics, 66(1, Part 2), 1-101.

La Porta, R., Lopez-de-Silanes, F., \& Shleifer, A. (2008). The economic consequences of legal origins. Journal of Economic Literature, 46(2), 285-332.

Landes, W. M., \& Posner, R. A. (1975). The independent judiciary in an interest-group perspective. Journal of Law and Economics, 18(3), 875-901.

Lange, M. K. (2004). British colonial legacies and political development. World Development, 32(6), 905-922.

Linzer, D. A., \& Staton, J. K. (2015). A global measure of judicial independence, 1948-2012. Journal of Law and Courts, 3(2), 223-256.

Locke, J. (1689). Two treatises of government. London: Awnsham Churchill.

Mill, J. S. (1859). On liberty. London: John W. Parker and Son.

Mukand, S. W., \& Rodrik, D. (2020). The political economy of liberal democracy. Economic Journal (forthcoming).

Neumayer, E., \& Plümper, T. (2017). Robustness tests for quantitative research. Cambridge: Cambridge University Press.

Nientiedt, D., \& Köhler, E. A. (2016). Liberalism and democracy: A comparative reading of Eucken and Hayek. Cambridge Journal of Economics, 40(6), 1743-1760.

Nozick, R. (1974). Anarchy, state and utopia. New York: Basic Books.

Olson, M. (1965). The logic of collective action: Public goods and the theory of groups. Cambridge, MA: Harvard University Press. 
Olson, M. (1993). Dictatorship, democracy and development. American Political Science Review, 87(3), 567-576.

Peltzman, S. (1976). Toward a more general theory of regulation. Journal of Law and Economics, 19(2), 211-240.

Pemstein, D., Marquardt, K. L., Tzelgov, E., Wang, Y., Krusell, J., \& Miri, F. (2018). The varieties of democracy measurement model: Latent variable analysis for cross-national and cross-temporal expert-coded data. V-DEM Working Paper 2018-21, Department of Political Science, University of Gothenburg.

Popper, K. (2013). The open society and its enemies. Princeton: Princeton University Press.

Rahman, A. A., \& Veenhoven, R. (2017). Freedom and happiness in nations: A research synthesis. Applied Research in Quality of Life, 13(2), 435-456.

Rawls, J. (1971). A theory of justice. Cambridge, MA: Belknap Press.

Sen, A. (1999). Development as freedom. Oxford: Oxford University Press.

Staton, J., Linzer, D., Reenock, C., \& Holsinger, J. (2019). Update. A global measure of judicial independence. https://doi.org/10.7910/DVN/NFXWUO.

Sunstein, C. R., Schkade, D., Ellman, L. M., \& Sawicki, A. (2006). Are judges political? An empirical analysis of the federal judiciary. Washington, D.C.: Brookings Institution.

Vanberg, G. (2008a). Establishing and maintaining judicial independence. In G. A. Caldeira, R. D. Kelemen, \& K. E. Whittington (Eds.), The Oxford handbook of law and politics (pp. 99-118). Oxford: Oxford University Press.

Vanberg, V. J. (2008b). On the complementarity of liberalism and democracy: A reading of F. A. Hayek and J. M. Buchanan. Journal of Institutional Economics, 4(2), 139-161.

Vásquez, I., \& Porčnik, T. (2018). The human freedom index 2018: A global measurement of personal, civil and economic freedom. Washington, D.C.: Cato Institute.

Verme, P. (2009). Happiness, freedom and control. Journal of Economic Behavior and Organization, 71(2), 146-161.

Voigt, S. (2013). How (not) to measure institutions. Journal of Institutional Economics, 9(1), 1-26.

Voigt, S. (2019). Institutional economics: An introduction. Cambridge: Cambridge University Press.

Voigt, S., \& Gutmann, J. (2013). Turning cheap talk into economic growth: On the relationship between property rights and judicial independence. Journal of Comparative Economics, 41(1), 66-73.

Voigt, S., Gutmann, J., \& Feld, L. P. (2015). Economic growth and judicial independence, a dozen years on: Cross-country evidence using an updated set of indicators. European Journal of Political Economy, 38(June), 197-211.

Waldron, J. (2006). The core of the case against judicial review. Yale Law Journal, 115(6), 1346-1406.

Welzel, C., \& Inglehart, R. (2005). Liberalism, postmaterialism and the growth of freedom. International Review of Sociology, 15(1), 81-108.

Welzel, C., Inglehart, R., \& Kligemann, H.-D. (2003). The theory of human development: A cross-cultural analysis. European Journal of Political Research, 42(3), 341-379.

Zakaria, F. (1997). The rise of illiberal democracy. Foreign Affairs, 76(6), 22-43.

Publisher's Note Springer Nature remains neutral with regard to jurisdictional claims in published maps and institutional affiliations. 